\title{
正常分娩直後に肺転移を起こした悪性絨毛上皮腫
}

\author{
劉応大学医学部三力内科 \\ 五味 二郎，吉沢 繁男，藤井玻凗 \\ 市川 陽一, 名越 秀樹 \\ 整応大学医学部病理学数室 \\ 重谷徹
}

\section{A CASE OF CHORIONEPITHELIOMA MANIFESTED BY PULMONARY METASTASIS IMMEDIATELY AFTER NORMAL DELIVERY}

\author{
Jiro Gom, Shigeo Yoshizawa, Herley FujI, \\ Yoichi ICHIKAwA and Hideki NAGOSHI \\ Department of Internal Medicine, School of Medicine, Keio University \\ Tohru KamEYA \\ Department of Pathology, School of Medicine, Keio University
}

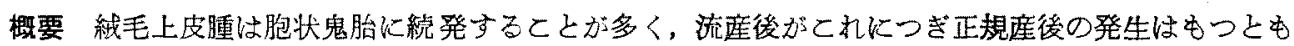

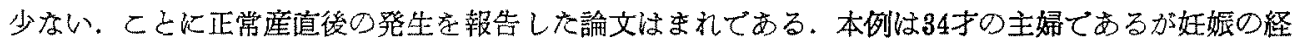
過中異常を諗めず，女児正常分婏した後，23日目飞乫然 $38^{\circ} \mathrm{C}$ 発熱，四吸困難，胸痛，血资が出現 した，両側中下肬野に水泡性ラ音を聽取し，胸部X線像上境界の不鮮明な細葉大陰影が全脑野に散在 し，一部で箅合していた，子宮は超手挙大，淡赤色の帯下定認めたが分娩直後であつたため，子宮复 古不全として重視されなふつた．剖検以より子宮䄉毛上皮腫および肺，肝，膵などへの広範な枟移が 発見された，絨毛上皮腫が時伅原発巣よりの症状に乏しく，呼吸器症状のみを呈することのあるのを 指摘し，乙の臨床症状，胸部X線所見の特徽につき考察した。
\end{abstract}

絨毛上皮腫は非常にまれに見られる奇形腫を除 けば，必ず妊娠によつて形成される絨毛膜細胞 trophoblastより発生するものである。そしてわ が国では分婏280回に1回の㓶合 $(0.36 \%)$ で発 生することが知られている，また先行妊娠の種類 をしらへると，盷状鬼胎に続発するものが任倒的 に多く，流産後加これにつぎ，正規産後に発生す るものは、はるかにまれである。

われわれはまつたく正常な妊娠，分婏にひきつ つき発生し，また発熱，呼吸困難，唍濑等の呼吸 器症状を主症状とし，原発坚の症状に乏しかつた

昭和39年 9 月12日 第160回関東地方会推蕉
ため診断に困惑した症例を経験したので報告す る.

\section{症 例}

患者：系○三○子，34才，主婦.

主訴：呼吸困難

家族歷：特記すへきものなし.

既往歷：13才の時肺浸溜にて 1 年間右側人工 気胸を施行. 30 才， 31 才の 2 回，人工妊娠中絶. 盷状鬼胎の既往はない。

現病歴：本学婦人科にて,人工受精を行ない, 佲和38年 4 月14日より19日までを最終月経として 妊娠した。その後順調に経過，39年 2 月10日，43 週にて女児を骨盤位にて正常分婏しだ。新生児体 
重 $2230 \mathrm{~g}$, 胎盤剥離正常, 後出血 $900 \mathrm{ml}$, 卵膜, 胎盤, 蟀帯, 羊水に異常を認めず, ことに胎盤の 欠損はまつたく認められなかつた，産裖に異常な く，2月17日退院した。

退院後, 赤色悪露が持続し，また呼吸に際し増 強する軽度の右胸痛に気付いた他, 特に变りなく 経過していた。3月5日（分娩後23日）に至り突 然 $38^{\circ} \mathrm{C}$ の発熱, 俨濑, 血痰, 胸痛, 呼吸困難が出 現した．近医にて下熱藥の注射を受け， $37.5^{\circ} \mathrm{C}$ 前 後に下降したが，呼吸困難，咳嗽が徐々に増强す るため, 3 月 10 日本学内科を受診, 即日入院した.

入院時所見：体格，栄養中等, 脈拍 120 整, 呼 吸浅く毎分 48 ，体動に際しチアノーゼが出現す る.眼瞼結膜貧血性, 眼球結膜に黄疸なく，舌に 白色舌苔を認めた，頝部リンパ節腫大せず，心掋 大なく，心音純. 右下肺野打診上短, 両側中・下 肺野に水泡性ラ音を聽取. 腹部では旰を 1 横指触 知，また右下腹部に圧痛を認めた。下肢に浮腫な く，腱反射は正常であつた．于宮は超手挙大で 軟, 少量の淡赤色の带下を認めた。

\section{諸検査成績}

1）尿；蛋白 $(+)$, ウロビリノーダン (土), 糖 (一), 尿沈渣, 赤血球 $2 \sim 3 / 1$ 視野, 白血球 4 $\sim 5 / 1$ 視野.

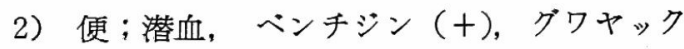
$(-)$, 虫卵 (一).

3）末梢血； 3 月11日: 赤血球 320万, 色素係 数 0.78 , ヘマトクリット $29.5 \%$, 白血球 9900 , 好 中球84\% ( I : 3, I : 33, II : 39, IV : 9), リン 分球15\%，単球 1\%. 3 月19日：赤血球 319 万, 白血球 24600 , 好中球 $89 \%$ （I：2，II : 17, II : 40, IV : $24, \mathrm{~V}: 5$, VI : 1), リンパ球 $8 \%$, 単球 $3 \%$, 栓球 13.8 万。

4）赤沈； $40 \mathrm{~mm} / 1$ 時間

5）喀痰; 獎粘液性, 新鮮血を混ずる.

（1）結核菌；塗抹，培養 5 回いずれも陰性.

（2）一般細菌；3月11日： strept. viridans $(+)$, staph. albus $(+), 3$ 月19日strept. viridans $(+)$, staph. aureus極少数.
（3）悪性腫瘍細胞； suspicious cells ( + ).

6) 䀒機能 ; 黄㾝指数 $6, \mathrm{~T} \mathrm{TT} 1.4, \mathrm{C} \mathrm{C}$ L F (-), al-P-ase 6.3u.

7）蛋白分画 : TP 6.2g/dl., A/G 0.7, $\alpha$-gl 1.2, $\beta$-gl 0.7, $\gamma$-gl 1.7g/dl.

8）血清電解質； 正常， NPN $33.1 \mathrm{mg} / \mathrm{dl}$.

9）血清梅毒反応； 陰性.

10）胸部X線検査；第 1 図ならびに第 2 図の ごとく両肺野に散布性陰影を認めた。大小不同が あるが多くは細葉性で，辺縁は不鮮明，右下肺野 ならびに左上肺野では癒合した像を示している. 右肺門リンパ節は腫大し，一部に石灰化像が認め られる。

入院後経過 : 肺結核の既往, 胸部X線像, およ び呼吸困難, 発熱, 血痰等の臨床症状より分娩後 急激に悪化した肺結核を考え抗結核藥, 強心藥の 投与, 輸夜等の治療を行なつた。しかし上記症状 は持続し, 胸痛ことに呼吸に際し増強する右胸痛 を訴えていた。3月20日前後より心烱部痛, 嘔気 が加わり，また肝は腫大し，2.5横指触知, 中等 度の圧痛を認めた。この頃より血痰も增加， 2 〜 $3 \mathrm{cc}$ 凝血を時々喀出するようになり，呼吸困難

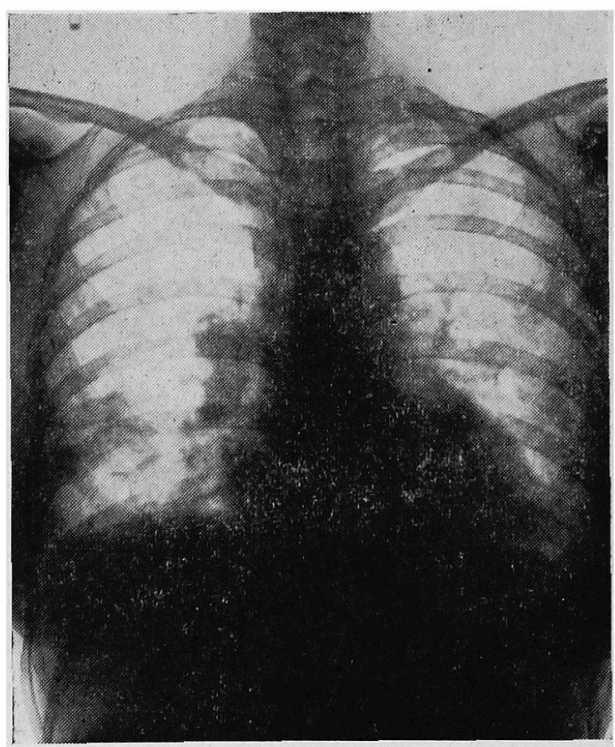

第 1 図 


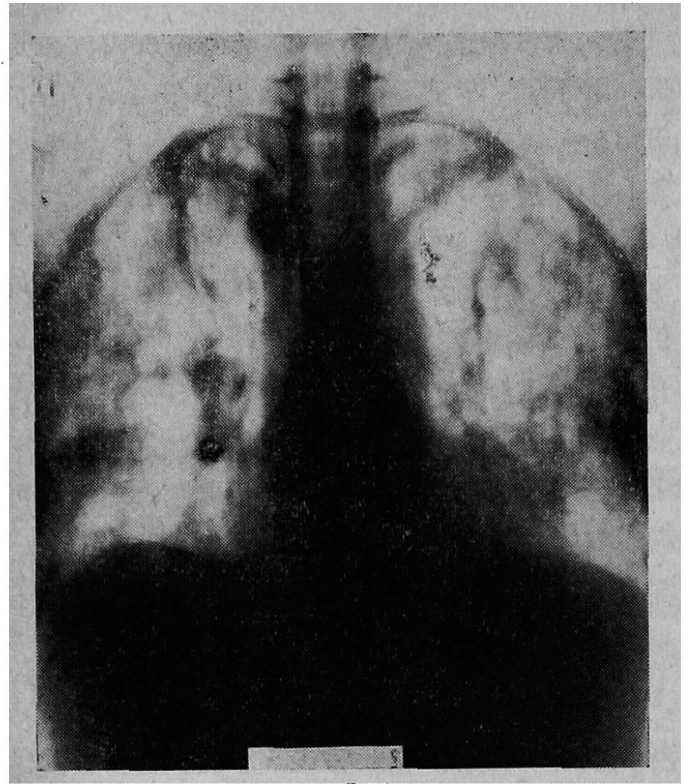

第 2 図

が増強し，全身状態も急激に悪化，3月23日（分 娩後41日目）に死亡した。

\section{剖検所見}

腹腔内に新鮮な血液約 $20 \mathrm{ml}$ を容し, 肺, 盰, 荤 に多数の黄色調を带びた出血性結節が散布してい た. 子宮は $9 \times 9 \times 7 \mathrm{~cm}$ で軟, 内腔の底部から体 部にかけ，前壁を基底として $6 \times 7 \times 4 \mathrm{~cm}$ 出血 性, 壞死性の腫瘍組織があり, 筋層深部にまで浸 潤し、こ〉にも著明な出血を伴なつていた，肺は 小指頭大, 灰白黄色の結節が全体ことに助膜に近 い部分に密に散在し, 周囲に広範な出血を伴なつ ていた。䀒，睟にも中心部が壊死におちいつた出 血性転移巣が多数認められた。この他大脳左後頭 葉に転移による $3 \times 4 \times 2 \mathrm{~cm}$ 極めて新らしい出 血巣が存在し,また空腸の孤立りンパ小結節 1 コ, 肺門部，傍気管支の各リンパ節に数コの転移 巣が認められた。なお右側助膜に陳旧性の線維性 癒着を認めたが，その他に両側助膜全体に比較的 新しい線維秋性瘁着が存在し, 肋膜直下の転移お よび肺胞内出血に伴なのたものと考えられた。

原発巣の組織所見を第 3 図に示したが, 出血 巣, 壊死組織の間吵に小塊をなした腫湟細胞群が

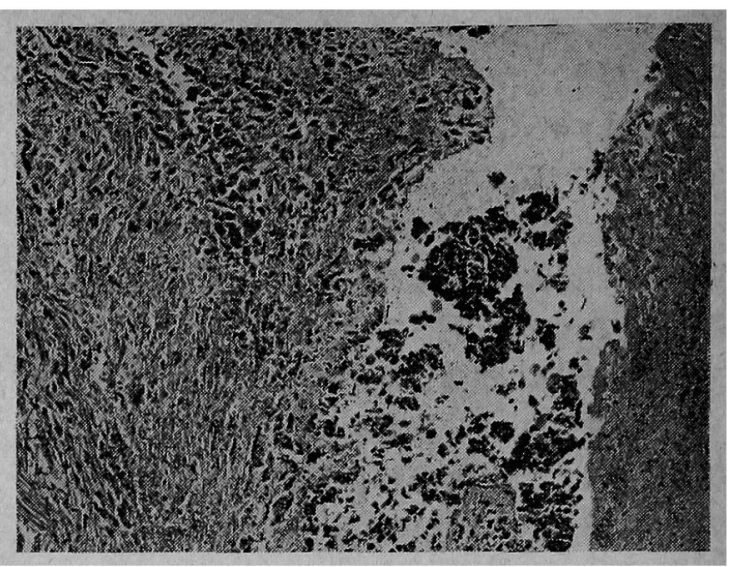

$$
\text { 第 } 3 \text { 図 }
$$

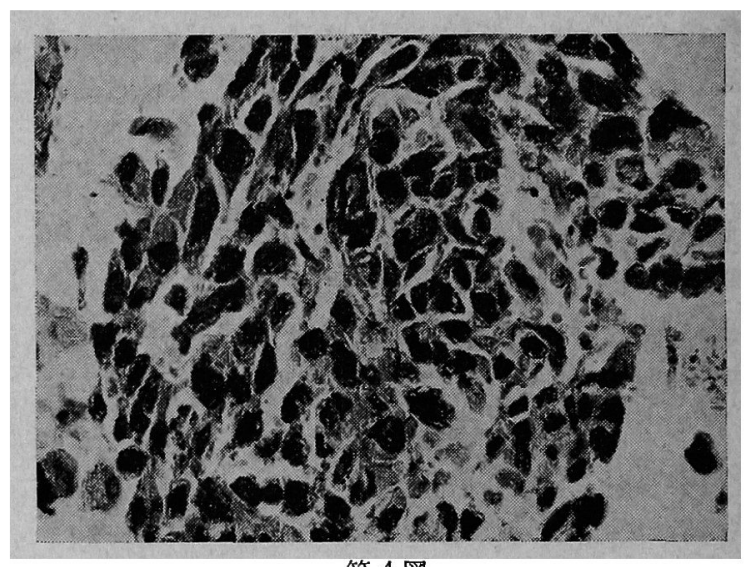

第 4 図

散在する．第 4 図はその強拡大写真であり, 著明 な異型性を示し，核はクロマチンに富んでいる. また細胞質は暗く，ところどころで互いに融合し ているのが認められる。すなわち，Langhans型 の淡明な細胞はほとんどなく，主として合胞細胞 (Synzitiumzellen) 類似の腫瘍細胞よりなつて いるといえる、その他全身に散在していた出血性 壞死性の結節も組織学的に同様の所見を認め,す ベて子宮䋐毛上皮腫の転移であることが判明し た. 全肺野に散在する腫瘍結節周囲の肺胞内は赤 血球が充満し，一部に炎症細胞の浸㵎を認めた。 また助膜に近い末梢小血管には多数の腫痬栓塞が 散在していた。

\section{考案}

わが国における絨毛上皮腫は，最近の長谷川ら 


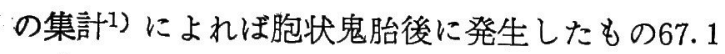
$\%$, 人工流産後 $16.9 \%$, 自然流産後 $9.8 \%$, 正規産 後 $6.0 \%$ ある。すすわち, 胞状鬼胎に続発した ものが過半数をしめ, 正規産後の発生がもつとも 少ない，その他の統計でも絨毛上皮腫のうち正規 産後に発生したものは関2によれば 126例中 9.6 $\%$ ，瀬木 ${ }^{3}$ )の報告では 506例中 $12.6 \%$ である. 正 規産の実数が胞状鬼胎よりはるかに多いことを考 えれば，正規産後の発生は極めて低率であるとい える.しかも，確実に正常分娩に続発したとする ためには，分婏にまつたく異常を想めないことと ともに，分娩後絨毛上皮腫の発生までに長期間を 経過せず, 新しい妊娠の介在する余地のないこと を確認することが必要である。このような見地か ら従来の文献をしらべてみると正常分娭後䋐毛上 皮腫の発生を報告しているものは少なく, 本邦で は最近10年間にわずか10数例にすぎない. 本症例 は妊娠, 分娩の経過中特に異常が認められず, 分 娭後 1 力月以内に登病している点確実に正常分婏 に続発したものと考えられる。しかしながら，以 上の事実は必ずしも䄉毛上皮腫が今回の正常分婏 後, その残遺胎盤より発生したことを示すもので はなく，奸娠早期に䄉毛成分が一部悪性化してい たとも考えられ，さらに先行流産の䄉毛成分より 発生したものが今回の妊娠と共存していた可能性 も否定できない4)。なお，緁毛上皮腫の発生頻 度, 先行妊娠の種類などにかんし, 欧米諸国と本 邦との間に著明な相違のあることが知られ，與味 ある事実と考えられるが,こ〉では主としてわが 国における成績を検討した。

絓毛上皮腫は比較的早期に全身に血行性転移を 起こす、転移部位は長谷川11の集計によれば肺が $42.5 \%$, 胵部 $30.1 \%$ どであり, その他の報告で も肺に多い点で一致している.また時として原発 巣の症状に乏しく，肺転移巣の症状のみを訴える ことが知られている.すでに阿武6)は原発巣の症 状に云しかつたため肺結核として治療を受けてい た症例を報告している.われわれの症例も不正出 血が出産にひきつづいていたため重視されず, 婦
人科医の診察によつても子宮復古不全とされ，ま た後産をも含め正常な分婏直後の発病であつたた め, 緁毛上皮腫の肺転移に思い至らなかつたこと は澡く反省される点である，そこで, 䄉毛上皮腫 の肺転移がどのような胸部X線像, 臨床症状を呈 し，またこれが他疾患のそれと鑑別し得るものか 否かについて文献的考察を加えたい.

䄉毛上皮腫の臨床症状として, 森》によれば不 正出血を93.3\%の高頻度に認めているが, 喛嗽, 胸痛, 血痰等呼吸器症状もそれぞれ $33.3 \%, 13.3$ $\% ， 13.3 \%$ と決して少なくなく, 剖検上肺転移の 多いことと一致している.また木部8) は, 肺転移 例19例につき検討し, 血痰16例, 咳嗽13例, 胸痛 14例, 呼吸困難を 8 例に認めている。すなわち血 痰は大多数の症例に認められ, 胸痛, 呼吸困難と ともに特街的な症状といえる。これは䄉毛上皮腫 が血管を障害し，出血を来たしやすいためであろ う.また, 比較的高頻度に認められる胸痛, 呼吸 困難の原因としては, 転移巣およびこれに伴なつ た広範な出血によるものが多いが, 肺転移例に少 なからず認められる腫瘍栓塞（第 5 図）もその一 因をなしているものと思われる。Bagshawe" 本疾患患者の肋膜痛, 血痰, 胸水貯留などの症状 は肺栓塞によるものが少なくなく，さらにわずか の体動に際し認められる強い呼吸困難も肺栓塞に 続発した急性肺高血圧症によるものであるとして

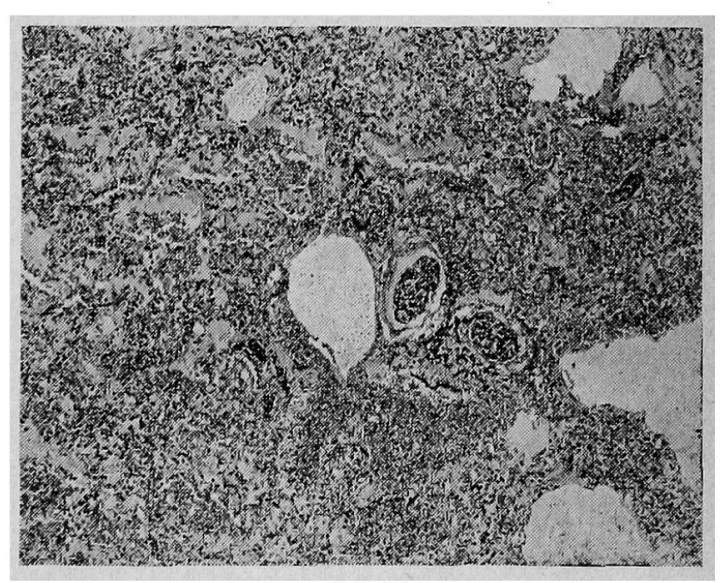

第 5 図 
いる。

胸部X線像にかんし，関2は，1）腫瘄が結節 として孤立しているもの，2）数個の結節が独立 して存在するもの，3) 多数の小結節が全肺野に 散在、または集塊をなすものの3 型に分類してい る、木部るはこれら結節型に加え浸潤型および肺 門型をあげている。そして胸部X楾像を剖検所見 と比較することにより本症に比較的高頻度にみ られる出血性肺硬塞および肺炎が浸㵎像を呈する としている. Bagshawe ${ }^{9}$ も肺転移を伴なつた䄉毛 上皮腫23症例の胸部X線像を分類し，1）一様な 濃度を有し辺縁が鮮明な陰影の散在するdiscrete type，2）辺縁がや > 不鮮明な陰影が全肺野に散 布されたsnow storm pattern,および3）腫湟柽 塞に起因するembolic patternに大別し，それぞ れの症例数は16例， 4 例，7例である.そして embolic patternとして腫瘍柽塞が多発した場合， あるいは比較的大きな血管に生じた場合，肺血管 抵抗の増大により右室およで肺血管陰影の塔大す ることを指摘している。

肺転移が結節状陰影を示す場合は一様な濃度の 境界鮮明な円形像であることが特徵であり，肺結 核は陰影に濃淡があり巣門結合の存在することに より鑑别され，また肺癌の陰影は辺縁が不規則で かつ周囲に浸閏を示すことが主な相違点としてあ げられている。しかしながら䋐毛上皮腫の肺転移 に種々の型のあること湔述の通りであり，肺 結核、肺蒸も無論多種多様な像を示し得るため
脢部X線像のみでは鑑別困難な場合が少なくな W.

䊼毛上皮腫は高頻度に肺転移を来たし，時とし て呼吸器症状のみを訴えて内科疾を受診する。し かも, 臨床症状, 胸部X線所見は前述のごとく必 ずしも特異的なものとはいえない，一方，䋐毛上 皮腫は肺転移を起こしたあとも抗癌藥および放射 線療法が著効を呈する場合がある、したがつて， 女性が血痰，胸痛，呼吸困難などの症状を訴える 場合, あるいは胸部X線検查で異常陰影を想めた 場合, 先行分婏の正常・異常にかかわらず䄉毛上 皮腫を常に考虑に入れ，必要があればゴナトトロ ビン定量など，婦人科的検索を行なう必要がある と思われる。

以上，正常分婏淔後に肺転移を来たし，呼吸困 難, 血痰など呼吸器症状を呈した䋐毛上皮腫の1 症例を報告し，あわせて絓毛上皮腫の肺転移に認 められる臨床症状につき文献的に考察を加えた。

\section{参考文献}

1）長谷川敏雄他：日産婦誌, $12: 1875,1960$. 2) 関閶: 日婦学誌, $37: 457,1942$. -3) 瀬木三 雄：産婦の世界， $7: 249,1955$, 一4) 夏目操 : 産 鲳人科の实際，8:703，1959，一5) Acosta-Sison: Philip. J. Cancer, $4: 122$, 1962. -6) 阿武保郎 他: 臨床々研究, $32: 493,1955 .-7)$ 森一郎他: 産科と䎑人科, $27: 1332,1960$ ，一8）木部純一： 東京医科大学雜誌, $18: 2071,1960.09)$ Bagshawe, K.D. et al.: Brit. J. Radiol., $36: 673$, 1963. 